\title{
Den gode krig?
}

\section{Peter Viggo Jakobsen}

\section{Hvorfor er de danske soldater i Helmand, holder begrundelserne for krigen til et nærmere eftersyn, og kan den overhovedet vindes?}

Mikkel Vedby Rasmussen: Den gode krig? - Danmark i Afghanistan 20062010. Gyldendal, København 2011. 149 sider.

Bogen har helt fortjent fået en masse roser af anmelderne for at gøre krigen i Afghanistan forståelig for menigmand og for at hæve blikket fra de enkelte træfninger i Helmand til det politisk-strategiske niveau og derved give læserne en forståelse af, hvilke overvejelser politikerne og embedsmændene i København har gjort om krigen. Spørgsmålene, Mikkel Vedby Rasmussen (MVR) ønsker at besvare, er ikke, hvorfor de danske soldater i Helmand går højre eller venstre om bakken, eller om de er gode til at løse deres opgaver det mener MVR, lige som de fleste andre, at de er. De danske soldater har gentagne gange ligget helt i top i NATO-evalueringer af de forskellige landes soldater. MVR spørger i stedet, hvorfor de i det hele taget er i Helmand, om begrundelserne for krigen holder til et nærmere efter- syn, og om krigen kan vindes.

Bogen er velskrevet og gør med brug af journalistiske virkemidler som individfokus og dramatisk nutid, emnet vedkommende og spændende. Bogen indskriver sig dermed i en ny og velkommen tendens inden for dansk samfundsvidenskab, hvor forskere i stigende grad søger at formidle deres viden på en lettilgængelig og interessant facon med det formål at levere et til tiltrængt indspark til samfundsdebatten.

MVR's bog er i så henseende lige så vellykket som Anja Dalgaard-Nielsens Umulig mission? (Gyldendal 2008), der ligeledes var et velformidlet og lettilgængeligt forsøg på at rejse en debat om, hvordan Danmark og de øvrige involverede vestlige allierede kunne omsætte soldaternes sejre i de daglige træfninger i Irak og Afghanistan til den bæredygtig fred og det demokrati, der var de erklærede endemål for begge indsatser.

Bogen adskiller fra de eksisteren- 


\section{LITTERATUR}

de bøger om det danske engagement i Afghanistan (A. C. Riebnitzsky: Kvindernes krig - en dansk soldats møde med Afghanistans kvinder. Politikens Forlag 2010; L. U. Johannesen: De danske tigre: Med livet som indsats $i$ Afghanistan. Gyldendal 2008; K. Hundevadt: I morgen angriber vi igen. Jyllands-Postens Forlag 2008) ved ikke at fokusere på soldaternes indsats i Helmand og ved at være meget mere kritisk.

Hvor disse bøger skildrer soldaternes indsats i et heroisk og positivt lys og giver det klare indtryk, at den nytter og gør en forskel, så mener MVR ikke, at det er tilfældet, hvis man løfter blikket fra de daglige kampe til det strategiske niveau.

\section{Strategisk fiasko}

I MVR's optik skildrer disse bøger helt korrekt en lang række taktiske militære succeser i Helmandprovinsen, men problemet er, at de skygger for en strategisk fiasko.

Danmark og resten af koalitionen vil ende med at tabe krigen uanset, om de vestlige soldater vinder hver eneste træfning med Taleban, fordi disse sejre ikke fremtvinger nogen militær afgørelse - Taleban sender bare nye krigere indover grænsen fra Pakistan, og fordi den vestlige koalition ikke kan overdrage magten til en stabil og legitim demokratisk valgt regering i Kabul, når den trækker sine soldater ud. Denne pessimisme er årsagen til spørgs- målstegnet i bogens titel.

Den står MVR ikke alene med. Pessimismen deles af mange andre forskere og analytikere i både Danmark og i udlandet, og selvom bogen ikke indeholder mange henvisninger til den internationale forskning og diskussion om Afghanistan, så tjener bogen på denne måde til at introducere denne internationale diskussion til et dansk publikum, fordi den ikke er blevet formuleret så klart og skarpt i en dansk sammenhæng før. Bogen leverer et originalt forskningsbidrag gennem sine interviews med centrale danske beslutningstagere. Et interessant interview med daværende forsvarschef Jesper Helsø dokumenterer således, at forsvarets ledelse selv ønskede at påtage sig ansvaret for midterområdet i den grønne zone selvom:

"Enhver tænkende hest, som bare har gået to år på Hærens officersskole, kunne se, at operationerne i midterområdet ville være hårde $\mathrm{og}$ potentielt farlige".

Det fremgår, at den danske forsvarsledelse lagde pres på briterne for at få midterområdet, da man ikke var interesseret i det sydlige område, som briterne først havde bedt de danske soldater om at overtage. Forsvarets ledelse valgte helt bevidst et meget farligt område, fordi man håbede at kunne få gang $\mathrm{i}$ en succesfuld genopbygning af hovedbyen Gereshk.

Valget af midterområdet med Gereshk var på papiret en god ide, der 
afspejlede en god forståelse i det danske forsvar for, hvordan man besejrer oprørsbevægelser. Det gælder om at vinde befolkningens hjerter og hjerner ved at demonstrere, at man kan tilbyde den en bedre fremtid end oprørerne. Ideen med at vælge Gereshk var, at Danmark kunne blive primus motor for en succesfuld genopbygning, der på sigt kunne bane vejen for større lokal opbakning og en marginalisering af Taleban.

Dermed ville de danske soldater ikke bare kunne gøre en forskel og bidrage til en realisering af det endemål, som Danmark og NATO havde opstillet for Afghanistan-operationen. En succesfuld genopbygning ville også gøre det lettere at bevare den brede politiske opbakning til operationen hjemme i Danmark, hvor partierne til venstre for midten konstant efterspurgte en større civil indsats.

I praksis lykkedes det imidlertid aldrig for alvor at få gang i genopbygningen i Gereshk, fordi Storbritannien og Danmark ikke afsatte de nødvendige civile ressourcer hertil. Selvom den danske regering aldrig forsømmer en lejlighed til at fremhæve sig selv som foregangsland for samtænkning - evnen til at vinde freden gennem en effektiv kombination af civile og militære ressourcer - så var forsvaret og udenrigsministeriet, som MVR viser, ikke villige til at prioritere den civile genopbygningsindsats i Gereshk, da det viste sig, at briterne ikke var i stand til at løfte opgaven. Som MVR påpeger, overtog Danmark midterområdet med Gereshk i 2007. Året efter var det danske genopbygningskontor stadig ikke permanent bemandet, og i 2009 var der kun tre civile rådgivere.

\section{Spørgsmålstegn ved den gode krig}

Den manglende sammenhæng mellem den overordnede forståelse af oprørsbekæmpelse og de konkrete militære operationer i Helmand er en af grundene til, at MVR stiller spørgsmålstegn ved, om Afghanistan var en god krig.

Bogens hovedbudskab er, at krigen var dårlig til trods for, at forsvaret viste sig til i stand til at kæmpe dygtigt og heroisk på lige fod med sine britiske og amerikanske partnere i de sværeste frontafsnit, til trods for at Udenrigsministeriet formåede at veksle forsvarets militære indsats til politisk goodwill i England, USA og NATO, og til trods for at de danske politikere formåede at mobilisere og fastholde en bred parlamentarisk og folkelig opbakning til krigen. Selv om Danmark har haft de største tab per indbygger (40 dræbte ultimo juni 2011) er den folkelige opbakning på omkring 50 procent stadig den højeste i alliancen.

Krigen var dårlig, fordi den i stedet for at skabe fred og demokrati i Afghanistan endte med at styrke Taleban, svække NATO, og fordi den 


\section{LITTERATUR}

endte som værdipolitik. Med det sidste mener MVR, at den danske regering brugte mere tid på at legitimere den danske krigsdeltagelse med henvisning til, at de danske soldater kæmpede for de rigtige værdier demokrati, menneskerettigheder og frihed - end på at forholde sig til om Danmarks militære og civile ressourcer blev anvendt mest hensigtsmæssigt. Frem for at fokusere på at vinde en strategisk sejr ved at udkæmpe den rigtige krig, kom diskussionen i Danmark i stedet til at handle om, at danske soldater ofrede sig heroisk for den gode sag $\mathrm{i}$ kampen mod det onde.

Og denne argumentationsform betød også, at enhver kritik af indsatsen kunne udlægges som forræderi over for de danske soldater og de værdier de kæmpede for.

Manglen på en strategi er MVR's største anke mod den danske krigsindsats i Afghanistan, og det er hans håb, at Danmark ikke igen vil gå i krig uden klare politiske mål, uden en ide om hvordan militær magt bedst anvendes til at nå de overordnede mål, og uden en plan for hvordan de danske soldater kan komme hjem igen. Dette håb brast allerede få dage efter bogens udgivelse $\mathrm{i}$ marts 2011, da alle folketingets partier vedtog at sende danske F-16 fly i krig i Libyen for at forhindre Gaddafi i at massakrere oprørsstyrkerne og civilbefolkningen omkring Benghazi. Beslutningen blev taget uden nogen dybere overvejelser om, hvad det overordnede endemål med den militære indsats skulle være, og hvordan man kom ud igen. Beslutningen fik da også MVR til at fare i blækhuset og kritisere de danske politikeres manglende vilje og evne til at tænke strategisk.

\section{For svag strategidiskussion}

Min største anke imod hans velskrevne og vellykkede bog er, at strategidiskussionen står for svagt. Man kan indvende over for bogens hovedargument om den manglende strategi, at Danmark har haft en klar overordnet strategi i Afghanistan, Irak og Libyen: nemlig at forblive i kridthuset hos de ledende stormagter - primært USA og Storbritannien. I alle de tre krige har Danmark ladet stormagterne formulere de overordnede mål, erklæret sig enige i dem og derefter betingelsesløst stillet sine begrænsede militære og civile ressourcer til disposition for dem. Danmark har hver gang krydset fingre for, at stormagterne ville bruge de danske ressourcer på en hensigtsmæssig måde, så de overordnede krigsmål blev nået.

MVR mener, at det er en alt for uambitiøs måde at føre krig på, og han insisterer på, at Danmark ved selv at tænke strategisk kan gøre en forskel og dermed øge sandsynligheden for, at anvendelsen af dansk militærmagt bidrager til at realisere de overordnede politiske mål som krigen startes for at sikre. Det rejser 
dog spørgsmålet om, hvor ambitiøs en småstat som Danmark kan være. Gider stormagterne lytte til danske beslutningstagere, der begynder at komme med gode råd om, hvordan en krig skal legitimeres, føres og afsluttes - hvor megen indflydelse fik Tony Blair lige på den amerikanske håndtering af Irak-krigen?

Man er også nødt til at spørge, hvornår en større og mere effektiv dansk indsats vil være nok til at gøre en strategisk forskel. Hvis vi nu forestiller os, at Danmark faktisk mente al sin snak om samtænkning alvorligt, og at det derfor i kraft af en større og bedre koordineret civil-militær indsats havde fået genopbygningen i Gereshk til at lykkes, så havde det jo alligevel ikke været nok til at vende udviklingen i Afghanistan.

Derfor tvivler jeg på, at Danmark realistisk set kan opnå meget mere med sin krigsdeltagelse end at skabe goodwill hos sine strategiske partnere i USA og Storbritannien. Danske soldater kan med en professionel indsats bidrage til sejr i de krige, hvor stormagterne har skruet mål og midler rigtigt sammen, men en professionel dansk militær indsats kan ikke afværge et strategisk nederlag, hvis mål og midler ikke hænger sammen. I et strategisk perspektiv handler dansk krigsdeltagelse derfor ikke om at vinde, men om at gøre USA glad ved at være med. Danmark kan nå sit strategiske hoved- mål selvom en krig går skidt. Det strategiske hovedmål for danske krigsindsatser er at bevare det amerikanske engagement i NATO, fordi det er den amerikanske sikkerhedsgaranti, som i sidste ende forhindrer, at der på ny kan opstå nye militære trusler mod det danske territorium. Set gennem de strategibriller har Afghanistan været en god krig, fordi Danmark har gjort hvad det kunne for at fastholde den amerikanske interesse i NATO.

Denne uenighed ændrer imidlertid ikke ved, at MVR skal have stor ros for sine bestræbelser for at starte en strategidiskussion i Danmark. Det er der i høj grad behov for ikke mindst i lyset af de store besparelser på to milliarder kr. om året, som forsvaret nu står overfor fra 2015. Disse besparelser kan kun gennemføres forsvarligt, hvis politikerne og forsvarets ledelse i fællesskab gør sig nogle overvejelser over, hvad det er for overordnede politiske mål, som det danske forsvar skal bruges til at fremme, hvordan det kan gøres med militære midler, og hvilke militære kapaciteter det danske forsvar som følge heraf skal råde over i fremtiden.

Alle danske beslutningstagere inden for det udenrigs- og sikkerhedspolitiske område burde derfor tvinges til at læse denne bog.

\section{Peter Viggo Jakobsen, Institut for Stra- tegi, Forsvarsakademiet.}

